\title{
Estrogen-Eluting Stents
}

\author{
Sung Kee Ryu • Ehtisham Mahmud • Sotirios Tsimikas
}

Received: 6 April 2009 / Accepted: 27 April 2009 / Published online: 19 May 2009

(C) The Author(s) 2009. This article is published with open access at Springerlink.com

\begin{abstract}
Coronary stenting is routinely utilized to treat symptomatic obstructive coronary artery disease. However, the efficacy of bare metal coronary stents has been historically limited by restenosis, which is primarily due to excessive neointima formation. Drug-eluting stents (DES) are composed of a stainless steel backbone encompassed by a polymer in which a variety of drugs that inhibit smooth muscle cell proliferation and excessive neointima formation are incorporated. DES have significantly reduced the incidence of restenosis but are also associated with a small $(\sim 0.5 \%$ per year $)$ but significant risk of late stent thrombosis. In that regard, estrogen-eluting stents have also undergone clinical evaluation in reducing restenosis with the additional potential benefit of enhancing reendothelialization of the stent surface to reduce stent thrombosis. Estrogen directly promotes vasodilatation, enhances endothelial healing, and prevents smooth muscle cell migration and proliferation. Due to these mechanisms, estrogen has been postulated to reduce neointimal hyperplasia without delaying endothelial healing. In animal studies, estrogen treatment was effective in decreasing neointimal hyperplasia after both balloon angioplasty and stenting regardless of
\end{abstract}

\footnotetext{
S. K. Ryu

Division of Cardiology, Department of Internal Medicine, Seoul Eulji Hospital, School of Medicine, Eulji University, Seoul, Republic of Korea

S. K. Ryu $\cdot$ E. Mahmud $\cdot$ S. Tsimikas

Division of Cardiology, University of California San Diego,

San Diego, CA, USA

S. Tsimikas $(\bowtie)$

Vascular Medicine Program, University of California San Diego,

9500 Gilman Drive, BSB 1080,

La Jolla, CA 92093-0682, USA

e-mail: stsimikas@ucsd.edu
}

the method of drug delivery. The first uncontrolled human study using estrogen-coated stents demonstrated acceptable efficacy in reducing late lumen loss. However, subsequent randomized clinical trials did not show superiority of estrogen-eluting stents over bare metal stents or DES. Further studies are required to determine optimal dose and method of estrogen delivery with coronary stenting and whether this approach will be a viable alternative to the current DES armamentarium.

\section{Keywords Estrogen · Drug-Eluting Stent}

\section{Effects of Estrogens on Blood Vessels}

Various cardioprotective properties of estrogens have been reported for decades [1]. One major beneficial effect is the improvement in the lipid profile with reduction of total and low-density lipoprotein cholesterol and increases in highdensity lipoprotein cholesterol in postmenopausal women $[2,3]$. Furthermore, in a recent study of 27,736 women, estrogen replacement was associated with significantly lower levels of lipoprotein(a) [4]. Estrogen also reduces fibrinogen and plasminogen activator inhibitor 1 levels, suggesting that it may possess enhanced fibrinolytic potential $[5,6]$. However, in the randomized, doubleblind, placebo-controlled Heart and Estrogen/progestin Replacement Study trial testing the efficacy and safety of estrogen plus progestin therapy for prevention of recurrent coronary heart disease (CHD) events in women, hormone replacement therapy did not reduce the incidence of CHD [7]. Unexpectedly, it did significantly increase the incidence of thromboembolic events compared to placebo.

Balloon angioplasty and stent placement routinely result in almost complete loss of the endothelial surface overlying 
the injured area. Over 1-6 months following the procedure, reendothelialization occurs by islets of endothelial cells dividing and filling in the gags over the injured subendothelial surface, which is an important factor in the recovery of the vessel wall from vascular injury [8]. This is particularly relevant in DES, where reendothelialization can be delayed or even prevented altogether, resulting in potential adverse effects [9]. Rapid reendothelialization prevents various unfavorable processes of vessel healing like smooth muscle cell (SMC) migration, excessive neointimal growth, and endothelial dysfunction. Estrogen promotes reendothelialization by enhancing vascular endothelial growth factor gene expression [10-12] and directly increases synthesis of nitric oxide (NO) with resultant vasodilatory effects and inhibition of SMC proliferation [1].

\section{Rationale for Development of Estrogen-Eluting Stents}

Intracoronary stenting is widely used for the treatment of obstructive coronary artery disease. Although stenting reduces the restenosis rate compared to balloon angioplasty $[13,14]$, neointimal proliferation after bare metal stenting still limits its efficacy. Endothelial cells control some aspects of the growth of SMC by release of NO, which has a growth-inhibitory effect, and blocks SMC which from circulating growth factors and secreting matrix proteins and proteoglycans. Following coronary stenting, the neointima generated is generally proportional to the degree of endothelial damage [8, 15]. Rapid endothelialization can prevent overgrowth of neointima, a major mechanism of instent restenosis. Therefore, promotion of endothelialization after stenting could be helpful in limiting in-stent restenosis.

DES have significantly reduced the rate of restenosis and subsequent target lesion revascularization compared to bare metal stents [16, 17]. The current formulations of DES are composed of stainless steel or cobalt chromium struts to which is attached a nondissolvable polymer imbedded with a variety of lipophilic drugs from the limus family (sirolimus, everolimus, zotarolimus, biolimus) or paclitaxel, which are either cytostatic or cytotoxic to SMC. These effects result in significant inhibition of SMC proliferation and ultimately in a reduction of excessive neointima formation. However, these drugs may also interfere with the normal healing mechanism of endothelialization after stent placement which may lead to increased risk of late stent thrombosis [18-21]. Unlike the drugs used in DES, estrogen could prevent restenosis by promoting endothelial healing and preventing SMC proliferation. Therefore,
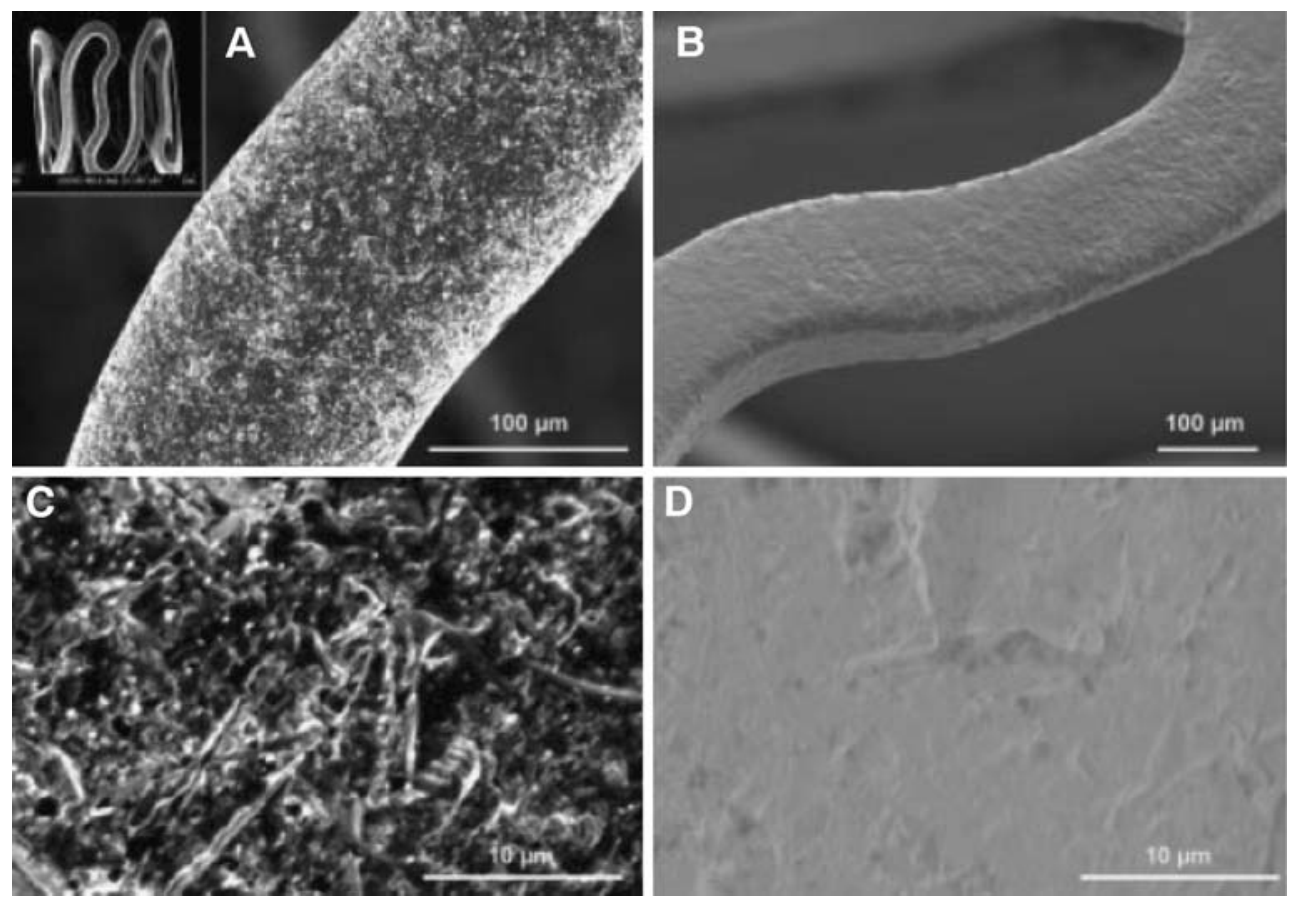

Fig. 1 The unique microporous surface of the ISAR stent platform allows for drug deposition and retards drug release without obligate application of a polymer. The roughness of the stent surface as determined by perthometer is $1.96 \pm 0.21 \mu \mathrm{m}$. Various kinds of drugs or drug combinations including rapamycin and estrogen can be loaded on ISAR stent with the same mechanism. A Uncoated microporous stent under a magnification of $\times 400$ illustrating the rough surface achieved

by mechanical treatment. The open-cell stent design is illustrated on the small photograph on the upper left corner. B Expanded microporous stent coated with $0.5 \%$ rapamycin solution (gold-sputtered to improve visibility, $\times 200$ ), visually highlighting uniform drug distribution across the entire stent surface. The surface of a noncoated $(\mathbf{C})$ and rapamycincoated (D) microporous stent at a magnification of $\times 1,000$. Reprinted with permission from Wessely et al. [22] 
several groups have generated estrogen-eluting stents for the prevention of restenosis. A description of an example of estrogen-eluting stents is shown in Fig. 1 [22]. The ISAR stent platform can deliver drugs such as rapamycin and estrogen. With its microporous surface, estrogen can be attached to the stent and released slowly.

\section{Animal Studies with Estrogen Stents}

In 1981, Beldekas et al. [23] reported that bovine aortic SMC cultured with 17- $\beta$-estradiol (17ßE) had reduced production of collagen. Chandrasekar et al. [24] showed that local delivery of $600 \mu \mathrm{g} 17 \beta \mathrm{E}$ reduced both the proliferative activity of SMC as well as neointimal hyperplasia after balloon injury of porcine coronary arteries [25]. New et al. [26] took this a step further by using a phosphorylcholine (PC)-coated estrogen-eluting stent and demonstrated a reduction in neointimal hyperplasia without delaying reendothelialization. A recent study using a similar porcine model [27] showed that intracoronary estrogen delivery using the InfusaSleeve catheter decreased percent stenosis by $47 \%(30 \rightarrow 16 \%)$ in balloon group and $23 \%(71 \rightarrow 55 \%)$ in stent group. In addition, type 1 collagen significantly correlated with the vessel wall injury scale and was reduced in the $17 \beta \mathrm{E}$ group. Overall, although publication bias cannot be ruled out, these experimental studies suggested a strong rationale for moving forward and assessing the role of estrogen-eluting stents in patients. It is also to be emphasized that many experimental studies are positive in animal models of restenosis, such as the rat carotid artery, rabbit iliac, and pig coronary arteries, but that the vast majority of compounds used in these models have not been successful in clinical trials.

\section{Human Studies with Estrogen Stents}

Table 1 describes the clinical studies evaluating estrogen coated stents. The first human study evaluating an estrogencoated stent used the BiodivYsio ${ }^{\mathrm{TM}}$ stent, where $17 \beta \mathrm{E}$ was loaded onto the stent just prior to insertion into the patients by dipping it in an estrogen solution. The BiodivYsio ${ }^{\mathrm{TM}}$ stent is a stainless steel stent coated with phosphorylcholine, which is present on phospholipids on the surface of cell membranes, to presumably optimize biocompatibility, although this has not been definitively demonstrated clinically. The Estrogen And Stents To Eliminate Restenosis (EASTER) trial [28] was

Table 1 Summary of clinical trials on estrogen-eluting stents

\begin{tabular}{|c|c|c|c|c|c|c|c|c|}
\hline Author & Year & No. & $\begin{array}{l}\text { Duration } \\
\text { of dual } \\
\text { antiplatelet } \\
\text { therapy }\end{array}$ & Study design & $\begin{array}{l}\text { Method of drug } \\
\text { coating }\end{array}$ & End point & Results & $\begin{array}{l}\text { Stent } \\
\text { thrombosis }\end{array}$ \\
\hline $\begin{array}{l}\text { Abizaid } \\
\text { et al. [28] } \\
\text { (EASTER) }\end{array}$ & 2004 & 30 & $\begin{array}{l}60 \text { days } \\
\text { (clopidogrel } \\
75 \mathrm{mg} \text { ) }\end{array}$ & $\begin{array}{l}\text { Single center, } \\
\text { no control } \\
\text { group }\end{array}$ & $\begin{array}{l}\text { On-site coating, } \\
\text { PC coat on } \\
\text { BiodivY sio } \\
\text { stent } 2.52-\mu \mathrm{g} / \mathrm{mm}^{2} \\
\text { stent surface }\end{array}$ & $\begin{array}{l}\text { 12-month clinical } \\
\text { data 6- month } \\
\text { coronary } \\
\text { angiography } \\
\text { and IVUS }\end{array}$ & $\begin{array}{l}\text { Good (late loss } \\
\quad 0.54 \pm 0.44 \mathrm{~mm} \text { ) }\end{array}$ & None \\
\hline $\begin{array}{l}\text { Airoldi } \\
\text { et al. [30] }\end{array}$ & 2005 & 108 & $\begin{array}{l}12 \text { weeks } \\
\text { (ticlopidine } \\
500 \mathrm{mg} \text { or } \\
\text { clopidogrel } \\
75 \mathrm{mg} \text { ) }\end{array}$ & $\begin{array}{l}\text { Multicenter } \\
\text { randomized } \\
17 \beta \mathrm{E} \text { on PC } \\
\text { coat vs. PC } \\
\text { coat only }\end{array}$ & $\begin{array}{l}\text { Precoated } \\
2.52-\mu \mathrm{g} / \mathrm{mm}^{2} \\
\text { stent surface }\end{array}$ & $\begin{array}{l}\text { 12-month clinical } \\
\text { data 6-month } \\
\text { coronary } \\
\text { angiography } \\
\text { and IVUS }\end{array}$ & $\begin{array}{l}\text { No difference in } \\
\text { clinical and } \\
\text { angiographic } \\
\text { outcome }\end{array}$ & $\begin{array}{l}3 \text { deaths or MI in } \\
\mathrm{PC} \text { coat group/no } \\
\text { death or MI in } \\
\text { estrogen group }\end{array}$ \\
\hline $\begin{array}{l}\text { Abizaid } \\
\text { et al. [31] } \\
\text { (ETHOS-1) }\end{array}$ & 2007 & 95 & $\begin{array}{l}2 \text { months } \\
\text { (ticlopidine } \\
500 \mathrm{mg} \text { or } \\
\text { clopidogrel } \\
75 \mathrm{mg} \text { ) }\end{array}$ & $\begin{array}{l}\text { Randomized, } \\
\text { double-blind, } \\
\text { multicenter } \\
\text { control vs. } \\
\text { slow release } \\
\text { vs. moderate } \\
\text { release }\end{array}$ & $\begin{array}{l}\text { Precoated } 250 \mu \mathrm{g} / \\
15 \mathrm{~mm} \text { of stent } \\
\text { length, moderate } \\
\text { release } 50 \% \text { in } \\
1 \text { day, slow } \\
\text { release } 50 \% \text { in } \\
8 \text { days }\end{array}$ & $\begin{array}{l}\text { 6-month percent } \\
\text { volume obstruction } \\
\text { by IVUS, clinical } \\
\text { outcome of } \\
6 \text { months }\end{array}$ & $\begin{array}{l}\text { No difference } \\
\text { in } \% \mathrm{VO} / \text { no } \\
\text { difference } \\
\text { in clinical } \\
\text { outcome }\end{array}$ & $\begin{array}{l}\text { Slow-release group } \\
1 \text { death/1 MI, } \\
\text { control and } \\
\text { moderate } \\
\text { release group no } \\
\text { death or MI }\end{array}$ \\
\hline $\begin{array}{l}\text { Adriaenssens } \\
\text { et al. [32] } \\
\text { (ISAR-PEACE) }\end{array}$ & 2007 & 502 & $\begin{array}{l}6 \text { months } \\
\text { (clopidogrel } \\
75 \mathrm{mg} \text { ) }\end{array}$ & $\begin{array}{l}\text { Randomized } \\
\text { rapamycin } \\
\text { vs. estradiol } \\
\text { plus rapamycin- } \\
\text { eluting stent }\end{array}$ & $\begin{array}{l}\text { On-site coating, none } \\
\text { PC coat, stainless } \\
\text { steel stent with } \\
\text { micropore } / 95 \% \\
\text { RES, } 60 \% \text { ERES } \\
\text { release in } 1 \text { month }\end{array}$ & $\begin{array}{l}\text { Primary: six month } \\
\text { in-stent } \\
\text { late lumen loss, } \\
\text { secondary: } \\
\text { binary restenosis, } \\
\text { TVR, death, } \\
\text { nonfatal MI }\end{array}$ & $\begin{array}{l}\text { No difference in } \\
\text { late lumen loss } \\
\text { and binary } \\
\text { restenosis rate/no } \\
\text { difference in } \\
\text { clinical outcome }\end{array}$ & $\begin{array}{l}\text { ERES } 2 \text { patients/ } \\
\text { RES } 3 \text { patients }\end{array}$ \\
\hline
\end{tabular}

RES rapamycin-eluting stent, ERES estrogen-rapamycin-eluting stent, IVUS intravascular ultrasound, $17 \beta E$ 17- $\beta$-estradiol, $P C$ phosphorylcholine, $V O$ volume obstruction, $M I$ myocardial infarction 
a single-center study of 30 patient study in which short $(<18 \mathrm{~mm})$, single, de novo lesions were treated. In this initial feasibility study, the number of patients was small; there was no control group; instead, each patient was used as their own control. With this version of the stent, drug was released for only the first $24 \mathrm{~h}$. Manual drug-loading methods may lack reproducibility and likely limit the amount loaded onto the stent and also result in rapid loss of estrogen from the stent once implanted in the coronary artery.

Six-month angiographic and intravascular ultrasound (IVUS) was performed and clinical follow-up was obtained at 12 months. The 6-month late luminal loss, defined as the minimal lumen diameter (MLD) at the end of the procedure minus the MLD at follow-up (6-9 months) angiography, was $0.54 \pm 0.44 \mathrm{~mm}$, which is less than the reported late loss of $0.95 \pm 0.61 \mathrm{~mm}$ with a PC-coated BiodivYsio ${ }^{\mathrm{TM}}$ stent without estrogen loading and also similar to results obtained with other bare metal stents [29]. The late loss was still greater than previously noted with the paclitaxel and sirolimuseluting stents $[16,17]$. Binary restenosis (diameter stenosis $>$ $50 \%$ ), another angiographic indicator of stent efficacy, occurred in only two patients and there were no major adverse cardiovascular events (MACE) reported at 12-month clinical follow-up. Neointimal hyperplasia as measured by IVUS was also significantly reduced compared to bare metal stents. Dual antiplatelet therapy was prescribed for only 60 days but there were no stent thromboses.

The next human trial was a randomized multicenter study in 104 patients in which preloaded 17ßE-eluting PCcoated BiodivYsio ${ }^{\mathrm{TM}}$ stents were used [30]. Study inclusion and exclusion criteria were similar to the EASTER trial but longer lesions $(<40 \mathrm{~mm})$ in larger diameter vessels $(4 \mathrm{~mm})$ were treated. Dual antiplatelet therapy (ticlopidine $500 \mathrm{mg}$ daily and aspirin $100 \mathrm{mg}$ daily) was administered for 12 weeks. There were no significant differences between the BiodivYsio ${ }^{\mathrm{TM}}$ stent without estrogen loading and the estrogen-coated BiodivYsio ${ }^{\mathrm{TM}}$ stent in late lumen loss, binary restenosis rate, or MACE rates. Overall, this study demonstrated safety and feasibility of $17 \beta$ E-eluting stents, but there was no superiority over the control group.

The estradiol-eluting stents in humans for restenosis trial (ETHOS-1) [31] performed by the same research group as the EASTER trial was a randomized multicenter study randomizing three groups of subjects: a control BiodivYsio ${ }^{\mathrm{TM}}$ stent without estrogen and two formulations of the BiodivYsio ${ }^{\mathrm{TM}}$ stent coated with $17 \beta \mathrm{E}$ in a slow versus moderate programmed-release preparation. To optimize short-term and long-term action of estrogen, approximately $50 \%$ of drug was released within 1 day in the moderate-release and 8 days in the slow-release groups, with the remainder of the drug eluted over 30 days. The estrogen dose was $240 \mu \mathrm{g} / 15 \mathrm{~mm}$ of stent length, representing the maximum dose that could be implanted on the stent. Oral clopidogrel was administered for 60 days. The main result of the study was that no differences in any efficacy measures were noted between the two groups at the 6-month angiographic and IVUS evaluation revealed

In the most recently published human study, ISAR-PEACE, the additive effect of estrogen on a rapamycin-eluting stent was evaluated [32]. To deliver the drugs, a polymer-free stainless steel stent with micropores was used. Dual antiplatelet therapy with aspirin and clopidogrel was done for 6 months. The primary end point was late lumen loss. In 250 patients, rapamycin-eluting stents (RES) were deployed and in 252 patients rapamycin plus estrogen-eluting stents (ERES) were deployed. Late lumen loss was not significantly different between the two groups (ERES $0.52 \pm 0.58 \mathrm{~mm}$, RES $0.51 \pm$ $0.58 \mathrm{~mm}$ ). The incidence of binary restenosis and stent thrombosis were not significantly different. Because an IVUS analysis was not performed, the effect of estrogen on neointima formation could not be evaluated.

\section{Conclusions}

In summary, human stent trials evaluating estrogen-eluting stents did not show any significant benefit over bare metal stents as suggested by animal studies. Although the animal models of restenosis and initial uncontrolled clinical studies were initially very promising, recent well-designed clinical trials have not show equivalence or superiority over bare metal stents or to have an additive efficacy when incorporated on existing DES. Despite theoretical vascular benefits of estrogen, no definitive explanation for the failure of estrogen-eluting stents in preventing restenosis has been provided. Based on the above studies, it is unlikely that estrogen-eluting stents will become clinically available without some new fundamental improvements in potency of estrogen compounds, elution kinetics, and/or improvements in stent design and incorporation of estrogen compounds.

Open Access This article is distributed under the terms of the Creative Commons Attribution Noncommercial License which permits any noncommercial use, distribution, and reproduction in any medium, provided the original author(s) and source are credited.

\section{References}

1. Mendelsohn, M. E., \& Karas, R. H. (1999). The protective effects of estrogen on the cardiovascular system. New England Journal of Medicine, 340, 1801-1811.

2. Manson, J. E., Hsia, J., Johnson, K. C., Rossouw, J. E., Assaf, A. R., Lasser, N. L., et al. (2003). Women's health initiative investigators. Estrogen plus progestin and the risk of coronary heart disease. New England Journal of Medicine, 349, 523-534.

3. The Writing Group for the PEPI Trial. (1995). Effects of estrogen or estrogen/progestin regimens on heart disease risk factors in postmenopausal women. The Postmenopausal Estrogen/Progestin Interventions (PEPI) Trial. JAMA, 273, 199-208. 
4. Suk Danik, J., Rifai, N., Buring, J. E., \& Ridker, P. M. (2008). Lipoprotein(a), hormone replacement therapy, and risk of future cardiovascular events. Journal of the American College of Cardiology, 52, 124-131.

5. Koh, K. K., Mincemoyer, R., Bui, M. N., Csako, G., Pucino, F., Guetta, V., et al. (1997). Effects of hormone-replacement therapy on fibrinolysis in postmenopausal women. New England Journal of Medicine, 336, 683-690.

6. Gebara, O. C. E., Mittleman, M. A., Sutherland, P., Lipinska, I., Matheney, T., Xu, P., et al. (1995). Association between increased estrogen status and increased fibrinolytic potential in the Framingham offspring study. Circulation, 91, 1952-1958.

7. Hulley, S., Grady, D., Bush, T., Furberg, C., Herrington, D., Riggs, B., et al. (1998). Randomized trial of estrogen plus progestin for secondary prevention of coronary heart disease in postmenopausal women. JAMA, 280, 605-613.

8. Kipshidze, N., Dangas, G., Tsapenko, M., Moses, J., Leon, M. B., Kutryk, M., et al. (2004). Role of the endothelium in modulating neointimal formation: vasculoprotective approaches to attenuate restenosis after percutaneous coronary interventions. Journal of the American College of Cardiology, 44, 733-739.

9. Choi, S. H., Prasad, A., \& Tsimikas, S. (2008). The evolution of thienopyridine therapy: clopidogrel duration, diabetes, and drugeluting stents. Journal of the American College of Cardiology, 51, 2228-2229.

10. Krasinski, K., Spyridopoulos, I., Asahara, T., van der Zee, R., Isner, J. M., \& Losordo, D. W. (1997). Estradiol accelerates functional endothelial recovery after arterial injury. Circulation, 95, 1768-1772.

11. Concina, P., Sordello, S., Barbacanne, M. A., Elhage, R., Pieraggi, M. T., Fournial, G., et al. (2000). The mitogenic effect of 17betaestradiol on in vitro endothelial cell proliferation and on in vivo reendothelialization are both dependent on vascular endothelial growth factor. Journal of Vascular Research, 37, 202-208.

12. Nickenig, G., Bäumer, A. T., Grohè, C., Kahlert, S., Strehlow, K., Rosenkranz, S., et al. (1998). Estrogen modulates AT1 receptor gene expression in vitro and in vivo. Circulation, 97, 2197-2201.

13. Serruys, P. W., de Jaegere, P., Kiemeneij, F., Macaya, C., Rutsch, W., Heyndrickx, G., et al. (1994). A comparison of balloonexpandable-stent implantation with balloon angioplasty in patients with coronary artery disease. Benestent Study Group. New England Journal of Medicine, 331, 489-495.

14. Fischman, D. L., Leon, M. B., Baim, D. S., Schatz, R. A., Savage, M. P., Penn, I., et al. (1994). A randomized comparison of coronary-stent placement and balloon angioplasty in the treatment of coronary artery disease. Stent Restenosis Study Investigators. New England Journal of Medicine, 331, 496-501.

15. Garg, U. C., \& Hassid, A. (1989). Nitric oxide-generating vasodilators and 8-bromo-cyclic guanosine monophosphate inhibit mitogenesis and proliferation of cultured rat vascular smooth muscle cells. Journal of Clinical Investigation, 83, 1774-1777.

16. Weisz, G., Leon, M. B., Holmes, D. R., Kereiakes, D. J., Clark, M. R., Cohen, B. M., et al. (2006). Two-year outcomes after sirolimus-eluting stent implantation: Results from the SirolimusEluting Stent in de Novo Native Coronary Lesions (SIRIUS) trial. Journal of the American College of Cardiology, 47, 1350-1355.

17. Aoki, J., Colombo, A., Dudek, D., Banning, A. P., Drzewiecki, J., Zmudka, K., et al. (2005). Peristent remodeling and neointimal suppression 2 years after polymer-based, paclitaxel-eluting stent implantation: insights from serial intravascular ultrasound analysis in the TAXUS II study. Circulation, 112, 3876-3883.

18. Joner, M., Finn, A. V., Farb, A., Mont, E. K., Kolodgie, F. D., Ladich, E., et al. (2006). Pathology of drug eluting stents in humans: delayed healing and late thrombotic risk. Journal of the American College of Cardiology, 48, 193-202.
19. Kaul, S., Shah, P. K., \& Diamond, G. A. (2007). As time goes by: current status and future directions in the controversy over stenting. Journal of the American College of Cardiology, 50, $128-137$.

20. Lagerqvist, B., James, S. K., Stenestrand, U., Lindbäck, J., Nilsson, T., \& Wallentin, L. (2007). SCAAR Study Group. Long-term outcomes with drug-eluting stents versus bare-metal stents in Sweden. New England Journal of Medicine, 356, 1009-1119.

21. Park, D.-W., Hong, M.-K., Mintz, G. S., Lee, C. W., Song, J.-M., Han, K.-H., et al. (2006). Two-year follow-up of the quantitative angiographic and volumetric intravascular ultrasound analysis after nonpolymeric paclitaxel-eluting stent implantation late "catch-up" phenomenon from ASPECT study. Journal of the American College of Cardiology, 48, 2432-2439.

22. Wessely, R., Hausleiter, J., Michaelis, C., Jaschke, B., Vogeser, M., Milz, S., et al. (2005). Inhibition of neointima formation by a novel drug-eluting stent system that allows for dose-adjustable, multiple, and on-site stent coating. Arteriosclerosis, Thrombosis, and Vascular Biology, 25, 748-753.

23. Beldekas, J. C., Smith, B., Gerstenfeld, L. C., Sonenshein, G. E., \& Franzblau, C. (1981). Effects of 17 beta-estradiol on the biosynthesis of collagen in cultured bovine aortic smooth muscle cells. Biochemistry, 20, 2162-2167.

24. Chandrasekar, B., \& Tanguay, J.-F. (2000). Local delivery of 17beta-estradiol decreases neointimal hyperplasia after coronary angioplasty in a porcine model. Journal of the American College of Cardiology, 36, 1972-1978.

25. Chandrasekar, B., Sirois, M. G., Geoffroy, P., Lauzier, D., Nattel, S., \& Tanguay, J.-F. (2005). Local delivery of 17-beta-estradiol improves reendothelialization and decrease inflammation after coronary stenting in porcine model. Thrombosis and Haemostasis, 94, 1042-1047.

26. New, G., Moses, J. W., Roubin, G. S., Leon, M. B., Colombo, A., Iyer, S. S., et al. (2002). Estrogen-eluting, phosphorylcholinecoated stent implantation is associated with reduced neointimal formation but no delay in vascular repair in a porcine coronary model. Catheterization and Cardiovascular Interventions, 57, 266-271.

27. Geraldes, P., Geoffroy, P., Cloutire, I., Sirois, M. G., \& Tanguay, J.-F. (2008). Local delivery of 17-beta-estradiol modulates collagen content in coronary porcine arteries after PTCA and stent implantation. Journal of Vascular Research, 45, 503-511.

28. Abizaid, A., Albertal, M., Costa, M. A., Abizaid, A. S., Staico, R., Feres, F., et al. (2004). First human experience with the 17-betaestradiol-eluting stent: the Estrogen And Stents To Eliminate Restenosis (EASTER) trial. Journal of the American College of Cardiology, 43, 1118-1121.

29. Shinozaki, N., Yokoi, H., Iwabuchi, M., Nosaka, H., Kadota, K., Mitsudo, K., et al. (2005). Initial and follow-up results of the BiodivYsio phosphorylcholine coated stent for treatment of coronary artery disease. Circ J, 69, 295-300.

30. Airoldi, F., Di Mario, C., Ribichini, F., Presbitero, P., Sganzerla, P., Ferrero, V., et al. (2005). 17-beta-estradiol eluting stent versus phosphorylcholine-coated stent for the treatment of native coronary artery disease. American Journal of Cardiology, 96, 664-667.

31. Abizaid, A., Chaves, A. J., Leon, M. B., Hauptmann, K., Mehran, R., Lansky, A. J., et al. (2007). Randomized, double-blind, multicenter study of the polymer-based 17-beta estradiol-eluting stent for treatment of native coronary artery lesions: six-month results of the ETHOS I trial. Catheter Cardiovasc Interv, 70, 654-660.

32. Adriaenssens, T., Mehilli, J., Wessely, R., Ndrepepa, G., Seyfarth, M., Wieczorek, A., et al. (2007). Does addition of estradiol improve the efficacy of a rapamycin-eluting stent? Results of the ISARPEACE randomized trial. J Am Coll Cardiol, 49, 1265-1271. 